\title{
The composition of high sugar ryegrasses
}

\author{
G.P. COSGROVE, J. KOOLAARD, D. LUO, J.L. BURKE ${ }^{1}$ and D. PACHECO \\ AgResearch Grasslands, PB 11008, Palmerston North \\ ${ }^{1}$ Institute of Veterinary, Animal and Biomedical Sciences, Massey University, PB 11222, Palmerston North \\ gerald.cosgrove@agresearch.co.nz
}

\begin{abstract}
Enhancing the concentration of water soluble carbohydrate (WSC) in ryegrass by management or breeding affects other chemical constituents, which may also contribute to the animal response. A large data set $(n=220)$ of chemical composition of 3 ryegrasses was examined to determine the relationship between elevated WSC and other constituents. Samples of pasture were collected at 8:00 am and 4:00 pm, 2-3 times per week during measurement periods in spring of 4 consecutive years and during autumn of 3 consecutive years, freezedried and concentrations of major constituents predicted by NIRS. Using a two-step statistical procedure effects due to year and day within season were removed, and then within season the concentration of WSC regressed, by six groups ( 3 cultivars $\mathrm{x}$ two times of day), against crude protein (CP), neutral detergent fibre (NDF), lipid and ash. For each grass a unit increase in WSC (slope) was offset by a decrease in CP of 0.62 units in spring $\left(\mathrm{R}^{2}=43 \%\right)$ and 0.44 units in autumn $\left(\mathrm{R}^{2}=47 \%\right)$, and a decrease in NDF of 0.30 units in spring $\left(\mathrm{R}^{2}=23 \%\right)$, and 0.17 units in autumn $\left(\mathrm{R}^{2}=42 \%\right)$. The $\mathrm{Y}$-axis intercepts differed for cultivar and time of day. For protein the decrease was greater than expected from the effect of dilution alone, and for NDF it was less than dilution. While the physiological basis for these relationships was not determined, they indicate that the reduction in protein and fibre should enhance the effect of greater WSC on the nutritional value of ryegrasses and the efficiency of nutrient utilisation in the animal.
\end{abstract}

Keywords: water soluble carbohydrate, perennial ryegrasses, high sugar grasses, protein, neutral detergent fibre

\section{Introduction}

Selective breeding (Humphreys 1989) and grazing management (Orr et al. 2001; Hoekstra et al. 2007) both offer opportunity to increase the concentration of water soluble carbohydrate (WSC) in ryegrasses. The rationale for increasing WSC has been that it boosts the supply of readily-available energy to support the microbial degradation of plant protein in the rumen (Kingston-Smith \& Theodorou 2000). This improves the incorporation of plant protein into microbial protein that ultimately becomes available in the lower digestive tract as a protein source to the ruminant
(Nocek \& Russell 1988). Such grasses are promoted to the pastoral industry for their ability to increase milk production or liveweight gain and, particularly relevant to the dairy industry, their ability to reduce the excretion of urinary nitrogen $(\mathrm{N})$. This excretion is an important environmental problem, as well as being wasteful in terms of utilisation of plant nutrients.

The animal production responses from grasses with higher concentrations of WSC have been inconsistent (Miller et al. 2001b; Moorby et al. 2006; Cosgrove et al. 2007a; Tas et al. 2005). There does not appear to be a direct relationship between a higher concentration of WSC and an increase in animal performance. In some studies, increases in WSC of less than $40 \mathrm{~g} \mathrm{WSC} /$ $\mathrm{kg}$ DM have resulted in animal responses (Miller et al. 2001b; Cosgrove et al. 2007a), whereas greater increases of up to $80 \mathrm{~g} \mathrm{WSC} / \mathrm{kg}$ DM have not (Moorby et al. 2006). It is apparent that chemical constituents of the plant other than just WSC are intricately involved in the animal response. For example, Lee et al. (2001) concluded that the higher liveweight gain of lambs grazing a high sugar (WSC) grass may have been due as much to an increase in dry matter intake because of the reduced concentration of structural fibre, as it was to the increase in WSC. Similarly, the lower fibre concentration of high WSC grasses may allow higher DM intake by zero-grazed dairy cows, but this does not always translate to higher milk production (Moorby et al. 2006), and was observed with cows at pasture (Miller et al. 2001a). These UK studies with dairy cows also demonstrated improvements in $\mathrm{N}$ utilisation, albeit with the grasses having atypically low concentrations of protein $(92-145 \mathrm{~g}$ crude protein $/ \mathrm{kg} \mathrm{DM})$. Where a higher concentration of WSC has resulted in a lower concentration of protein it has been argued that maintaining even the same level of milk production on a low protein grass is substantive evidence of benefit from the higher WSC (Miller et al. 2000; Miller et al. 2001a). However, in New Zealand, with higher concentrations of protein (e.g. a mean of $220 \mathrm{~g} / \mathrm{kg} \mathrm{DM}$ in 6300 pastures samples; Litherland \& Lambert 2007), benefits from improved protein nutrition are not as likely. And, while reducing $\mathrm{N}$ excretion is important, the currently available high sugar grasses may not have enough WSC to markedly improve the utilisation of N 
when the concentration of protein is high (Pacheco et al. 2007; Pacheco et al. 2009).

When breeders select for a specific trait, in this case WSC, the concentrations and proportions of other constituents are also influenced. Some of these (e.g. fibre) are as important to determining the animal response as is the selected trait itself, while for others (e.g. protein) the change may or may not be in the range that affects the animal response, but can have a large effect on related aspects such as environmental impact. This paper reports on an investigation of a large dataset on the chemical composition of three ryegrasses differing in the concentration of WSC, sampled at different times of day, and in different seasons and years. This analysis was conducted to determine if the changes in other plant constituents associated with elevated WSC are consistent and predictable. This understanding is necessary for interpreting the animal response across different studies, and would be useful to inform plant breeders where greater performance gains from future selection could be achieved by taking into account associated traits, as well as the primary trait.

\section{Materials and Methods}

The pasture samples used for the analysis of relationships reported here were collected from a field study on the role of high sugar grasses in pasturebased dairy production systems, during successive spring and autumn periods from 2004-2008. This study was conducted at Massey University's No 4 Dairy Farm, located on a Tokomaru silt loam soil near Palmerston North.

\section{Treatments and experimental design}

The study compared three endophyte-free ryegrasses: a standard New Zealand (NZ) diploid perennial ryegrass (STG, Lolium perenne, cv. 'Grasslands Impact'), a UK "high sugar" diploid perennial ryegrass (HSG, cv. 'AberDart',) and a NZ tetraploid Italian ryegrass (IRG, Lolium multiflorum, cv. 'Grasslands Moata'). The treatment design allowed for the effects of higher WSC to be evaluated by comparing 1) between perennials and 2) annual vs perennial.

Milk production and nitrogen partitioning were measured during each spring for about 6 weeks and for 2-4 weeks each autumn. Details of these aspects of the study and interim results have been presented elsewhere (Cosgrove et al. 2007a; Pacheco et al. 2009).

\section{Pastures}

In autumn 2004, seven paddocks (about 2 ha each) were sown with the STG and HSG perennial ryegrasses at $16 \mathrm{~kg} \mathrm{seed} / \mathrm{ha}$ following full cultivation. For each paddock, one half was randomly selected and sown
Table 1

The duration of sampling and the number of sampling occasions during the spring and autumn from 2004-2008.

\begin{tabular}{|c|c|c|c|c|}
\hline Year & Season & Start date & End date & $\begin{array}{c}\text { Number of } \\
\text { samples }\end{array}$ \\
\hline 2004 & Spring & Nov 1 & Dec 16 & 16 \\
\hline 2005 & Spring & Sept 29 & Nov 3 & 23 \\
\hline \multirow[t]{2}{*}{2006} & Autumn & April 6 & June 1 & 11 \\
\hline & Spring & Sept 14 & Feb $8^{1}$ & 18 \\
\hline \multirow[t]{2}{*}{2007} & Autumn² & April 4 & May 21 & 9 \\
\hline & Spring & Oct 25 & Dec 10 & 15 \\
\hline 2008 & Autumn & May 8 & June 5 & 13 \\
\hline
\end{tabular}

${ }^{1}$ Sampling extended into summer of this year.

${ }^{2}$ There was no Italian ryegrass sampled during autumn 2007.

with STG and the other half sown with HSG. Of these seven paddocks, five had previously been in turnips for late-summer feed, one in Italian ryegrass and one in perennial ryegrass. A further three paddocks ( 2 ha; ex-turnips) were sown with the Italian ryegrass at 30 $\mathrm{kg}$ seed/ha. New paddocks of Italian ryegrass were established in autumn 2006. Each of the ryegrass types was sown as a monoculture, and swards were maintained in this condition by spraying each winter to remove volunteer white clover and weeds. In addition to farm maintenance applications of $\mathrm{P}, \mathrm{K}$ and $\mathrm{S}$ fertiliser, $\mathrm{N}$ was applied at $35 \mathrm{~kg} / \mathrm{ha} 5-6$ times annually.

\section{Pasture management}

During the non-experimental periods trial paddocks were grazed by the farms main herd as part of the normal farm rotation. No hay or silage was fed on these paddocks to minimise contamination from foreign seed.

\section{Pasture allocation}

During measurement periods, each treatment group of cows was offered a fresh break of grass twice daily, at 8:00 am and at 4:00 pm, immediately following milking. The targets for pre- and post-grazing pasture mass were $2600 \mathrm{~kg} \mathrm{DM} / \mathrm{ha}$ and $1600 \mathrm{~kg} \mathrm{DM} / \mathrm{ha}$, respectively.

\section{Sampling}

Pasture sampling encompassed the animal measurement period within each season and in some cases started earlier and continued for longer (Table 1), and for spring 2006 extended into summer. Within season, the exact timing of these periods of measurement was influenced by seasonal conditions (e.g. sufficient grass growth rate to support the trial cows) and they were not identical from year to year. Samples of the pasture offered to cows were taken at 8:00 am and at 4:00 pm, 2-3 times 
Table 2 The overall mean concentrations $(\mathrm{g} / \mathrm{kg} \mathrm{DM})$ of the five constituents of ryegrass, the estimates of slope, percentage variance accounted for (adjusted $\mathrm{R}^{2}$ ) and the $95 \%$ confidence interval of the slope of the pairwise relationships of each major constituent regressed on water soluble carbohydrate during spring and autumn (ryegrass cultivars did not differ from each other in slope). The hypothesised slope is that expected from the effect of dilution alone (see Materials and Methods for further explanation).

\begin{tabular}{|c|c|c|c|c|c|c|}
\hline Season & Constituent & Mean & Slope & $\mathrm{R}^{2}$ & $\begin{array}{c}\text { Confidence } \\
\text { interval }\end{array}$ & $\begin{array}{l}\text { Hypothesised } \\
\text { slope }\end{array}$ \\
\hline \multirow[t]{5}{*}{ Spring } & $\begin{array}{l}\text { Water soluble } \\
\text { carbohydrate }\end{array}$ & 201 & - & - & - & - \\
\hline & Crude protein & 208 & -0.62 & 43.4 & \pm 0.08 & -0.33 \\
\hline & Neutral detergent fibre & 433 & -0.30 & 23.2 & \pm 0.09 & -0.50 \\
\hline & Ash & 92 & -0.20 & 61.0 & \pm 0.02 & -0.13 \\
\hline & Lipid & 34 & -0.05 & 10.5 & \pm 0.01 & -0.04 \\
\hline \multirow[t]{5}{*}{ Autumn } & $\begin{array}{l}\text { Water soluble } \\
\text { carbohydrate }\end{array}$ & 157 & - & - & - & - \\
\hline & Crude protein & 264 & -0.44 & 47.2 & \pm 0.12 & -0.34 \\
\hline & Neutral detergent fibre & 388 & -0.17 & 41.8 & \pm 0.19 & -0.42 \\
\hline & Ash & 110 & -0.13 & 71.1 & \pm 0.02 & -0.13 \\
\hline & Lipid & 40 & -0.03 & 3.6 & \pm 0.03 & -0.04 \\
\hline
\end{tabular}

per week. On each occasion 6 samples were collected (3 cultivars $\mathrm{x}$ morning and afternoon), except for autumn 2007 when no Italian ryegrass was available. Separate samples were taken in the morning (am) and afternoon ( $\mathrm{pm})$ to account for the diurnal changes in chemical composition, especially WSC. Samples were collected from the next break in the grazing sequence, because the cows generally returned to their paddocks before 8:00 am and 4:00 pm and pasture on offer was partially consumed by the scheduled sampling time. These samples were hand-plucked to grazing height to represent herbage being consumed by the cows in each treatment. The pasture samples were immediately frozen in liquid nitrogen in the field, stored frozen, and subsequently freeze-dried and ground using a $1-\mathrm{mm}$ sieve size. They were then analysed using near-infrared reflectance spectroscopy, calibrated for high WSC grasses (FeedTech, AgResearch Grasslands, Palmerston North), to estimate the concentrations of WSC, crude protein, neutral detergent fibre, lipid and ash.

\section{Statistical analysis}

The statistical analysis was conducted using the concentrations of WSC, crude protein, neutral detergent fibre, lipid and ash, the five major chemical constituents which in sum account for plant composition (overall 968 $\mathrm{g} / \mathrm{kg}$ in spring and $959 \mathrm{~g} / \mathrm{kg}$ in autumn, the discrepancies from $1000 \mathrm{~g}$ being the cumulative error associated with NIRS prediction of each constituent). The data for each season separately was first adjusted to account for the effects of year and also a linear trend of day (that is, day within the period of measurement). After that, WSC, being the constituent of interest, was used as the explanatory variable and the other four constituents regressed in a pairwise manner on WSC. The grouped regression was conducted separately for spring and autumn, and allowed for separate slopes and intercepts (if required) for each of the three ryegrasses and for am and $\mathrm{pm}$. Separate am and pm groups were included to expand the range of values of WSC as explanatory variables, enhancing the detection of relationships that existed. T-tests were used to compare intercepts from the regression analysis. Actual slopes were compared against a hypothesised slope, that indicated the expected relationship if the effect of WSC on the Y variable was due entirely to dilution. Where the hypothesised slope lay outside the confidence limits of the actual slope, the deviation indicated the response in the $\mathrm{Y}$ variable was more than simple dilution. The hypothesised slope for 
Figure 1 Scatter-plot and fitted lines for crude protein (CP) and neutral detergent fibre (NDF) regressed in a pairwise manner on water soluble carbohydrate for three cultivars of ryegrass; a high sugar ryegrass (HSG), a control perennial ryegrass (STG) and a control Italian ryegrass (IRG), sampled morning (am) and afternoon (pm) in spring over 4 years, and in autumn over 3 years (relationships for ash and lipid not shown). Note different scales.

Spring

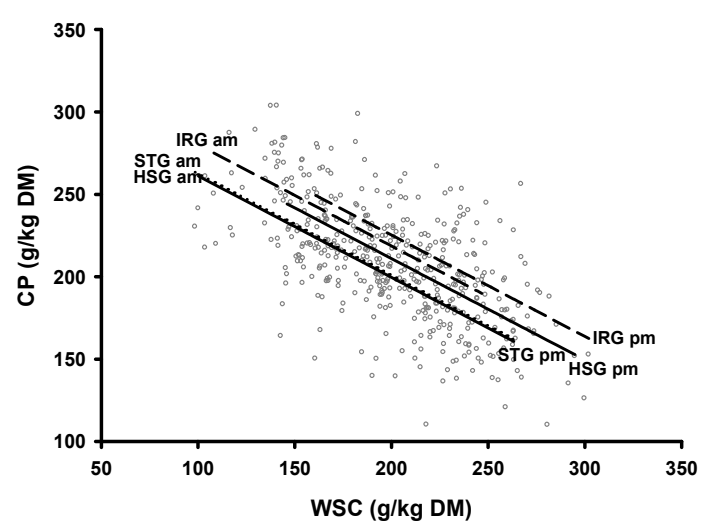

Autumn

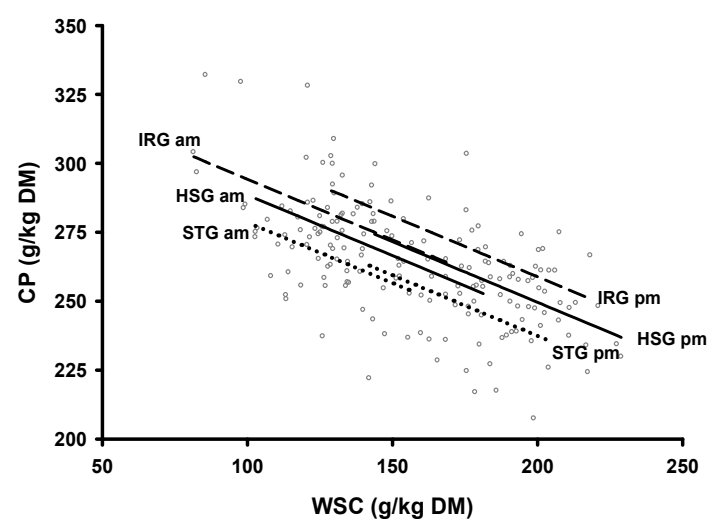

each constituent was determined as the $\mathrm{Y}$-axis intercept (i.e. $\mathrm{WSC}=0$ ) from the pairwise regression relationship (this is equivalent to the proportion of that constituent in the WSC-free DM; see Hoekstra et al. 2007).

\section{Results}

The overall mean concentrations of the major constituents during spring and autumn, and the slope and percentage variance accounted for (adjusted $\mathrm{R}^{2}$ ) of the pairwise relationships of crude protein, neutral detergent fibre, lipid and ash regressed on water soluble carbohydrate are shown in Table 2. The scatter plots for the relationship with protein and fibre are shown for spring and for autumn (Fig. 1). There was no evidence from the data that the slopes of the relationships differed among the 3 ryegrass cultivars or between morning and afternoon samples, so parallel
Spring

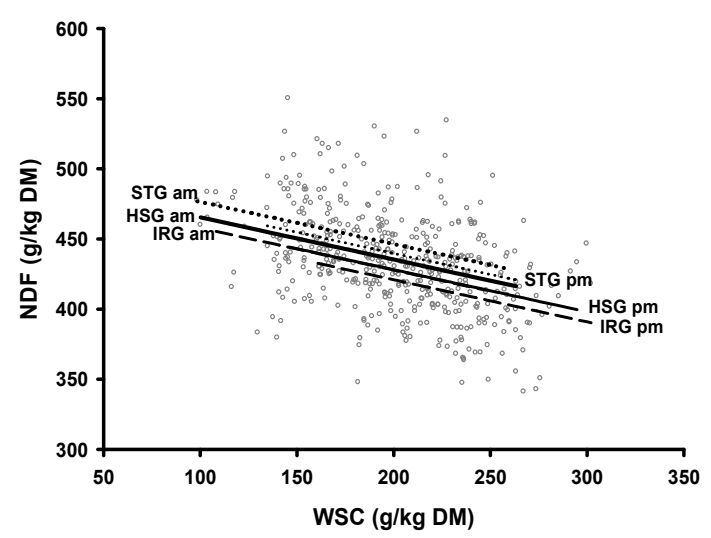

Autumn

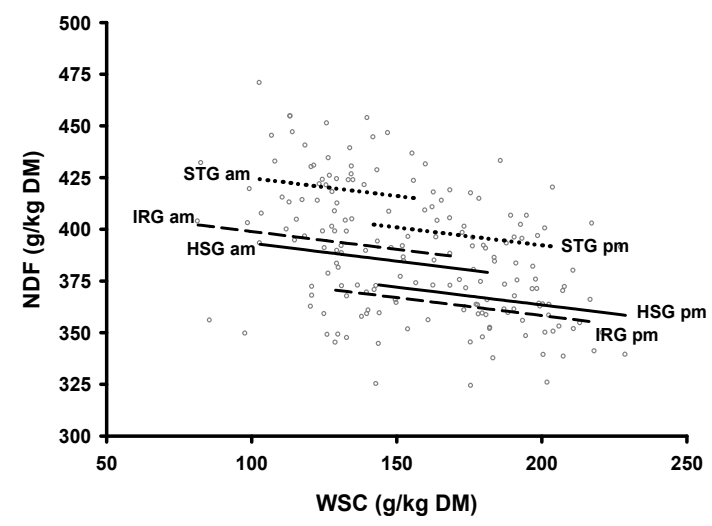

lines were fitted. For each unit increase in WSC, crude protein changed most (reductions of 0.62 and 0.44 units for spring and autumn, respectively), followed by fibre (reductions of 0.30 and 0.17 units for spring and autumn, respectively). Comparing the slope for each relationship against the hypothesised slope reveals if the reduction in any constituent as WSC increases can be explained by dilution (hypothesised slope is within the confidence interval of the fitted slope) or is other than dilution (hypothesised slope is outside the confidence interval of the fitted slope). The reduction in neutral detergent fibre in both spring and autumn is less than expected as a consequence of dilution, whereas for crude protein the reduction is greater (significant for spring only). For lipid, and ash in autumn, the change can be explained by dilution alone.

The intercepts differed among grasses (Table 3). At 
Table 3 Estimates of the intercepts for the pairwise relationships for crude protein (CP), neutral detergent fibre (NDF), ash and lipid regressed on water soluble carbohydrate for three cultivars of ryegrass; a high sugar ryegrass (HSG), a control perennial ryegrass (STG) and a control tetraploid Italian ryegrass (IRG), during spring and autumn. Significant differences with respect to the reference cultivar (HSG) are indicated by $P$ values.

\begin{tabular}{|c|c|c|c|c|c|c|}
\hline \multirow[b]{2}{*}{ Season } & \multirow[b]{2}{*}{ Constituent } & \multicolumn{3}{|c|}{ Cultivar } & \multicolumn{2}{|c|}{$P$} \\
\hline & & HSG & STG & IRG & HSG vs. STG & HSG vs. IRG \\
\hline \multirow[t]{4}{*}{ Spring } & $\mathrm{CP}$ & 328 & 324 & 345 & 0.75 & $<0.001$ \\
\hline & NDF & 492 & 503 & 484 & 0.03 & 0.14 \\
\hline & Ash & 131 & 132 & 135 & 0.14 & $<0.001$ \\
\hline & Lipid & 45 & 44 & 44 & 0.21 & 0.56 \\
\hline \multirow[t]{4}{*}{ Autumn } & $\mathrm{CP}$ & 335 & 324 & 343 & 0.01 & 0.19 \\
\hline & NDF & 404 & 434 & 405 & $<0.001$ & 0.40 \\
\hline & Ash & 129 & 129 & 132 & 0.66 & 0.001 \\
\hline & Lipid & 45 & 44 & 44 & 0.06 & 0.42 \\
\hline
\end{tabular}

$\mathrm{P}$ - values are from $\mathrm{t}$ tests for the null hypothesis of a zero difference between the associated intercepts.

a given concentration of WSC, in spring the IRG had more $\mathrm{CP}(\mathrm{P}<0.001$, based on a t-test comparison of intercept values) and the STG had more NDF $(\mathrm{P}=0.03)$, compared with the reference cultivar HSG. In autumn, the STG had less CP $(\mathrm{P}=0.01)$ and more NDF $(\mathrm{P}<0.001)$ than the HSG.

\section{Discussion}

The project for which this dataset on pasture composition forms a part, aims to determine the merits of ryegrasses selected for higher concentrations of water soluble carbohydrate. That requires establishing a clear link between the constituent of interest and the animal response. Responses to increased WSC in animal production and improvements in the efficiency of nitrogen utilisation have been recorded in some studies (e.g. Lee et al. 2000; Miller et al. 2001b; Cosgrove et al. 2007a, b) but not others (Miller et al. 2000; Miller et al. 2001a; Moorby et al. 2006; Cosgrove et al. 2007a). The factors that influence whether or not there is a response to increased WSC are not clear. Preliminary analysis and interpretation of pasture composition data collected in different seasons and years indicated that other chemical constituents vary in association with the increased WSC, and contribute to the animal response. For example, the concentrations of both $\mathrm{N}$ and WSC, and their ratio, influence the efficiency of $\mathrm{N}$ utilisation and excretion of surplus $\mathrm{N}$ (Cosgrove et al. 2007b; Pacheco et al. 2007; Pacheco et al. 2009). Similarly, the concentration of fibre affects DM intake, and the intake of $\mathrm{N}$, and therefore, has a direct effect on animal production and $\mathrm{N}$ retention and excretion, independently of the effects of WSC. The link between cause (higher WSC) and effect (animal response) may be complex, and the associated changes in composition may be as influential as WSC in determining the animal response. Understanding the factors that influence the proportions of the major constituents would provide valuable progress towards predicting the conditions under which animal responses to increased WSC will occur.

The data set of chemical composition for high WSC grasses and controls, collected morning and afternoon during spring and autumn spanning 4 years provided a basis for examining relationships among major constituents that determine the nutritive value of grass. It also provided a basis to determine if elevated WSC in ryegrasses, achieved by capturing the late-afternoon peak in the concentration of sugars derived from photosynthesis or by selective breeding, has predictable effects on other constituents. If one constituent increases, it follows that the proportions of the other constituents in the total dry matter will decrease as a consequence of dilution. The comparisons of fitted slopes against hypothesised slopes revealed that as WSC increased neutral detergent fibre decreased less than expected from dilution and protein decreased 
more than expected. From an animal's perspective whether these effects are dilution alone or have more fundamental causes does not affect the nutritional consequence. The reductions in both protein and fibre as WSC increases would be favourable for animals grazing pastures in most circumstances in New Zealand, and the higher ratio of WSC:protein would have environmental benefits through improving the efficiency of nitrogen utilisation (Pacheco et al. 2007). However, from the perspective of plant function the cause is important. The fibre fraction may actually be increasing as a proportion of the non-WSC constituents, consistent with observations for high-WSC grasses under controlled environment conditions (Rasmussen et al. 2009). The greater reduction in protein and the smaller reduction in fibre (relative to the dilution expectations) may affect physiological processes and warrant further consideration as part of breeding and selection to increase WSC.

There are two aspects of the relationships that are important. Firstly, for both spring and autumn, at any given concentration of WSC, the high-WSC ryegrass and the Italian ryegrass had more protein and less NDF than the control ryegrass (different intercepts in the relationships shown in Fig. 1). While complex, this may help explain previous observations (Cosgrove et al. 2007a) of a milksolids production response in autumn, in the absence of any difference in WSC. A previous study (see Pacheco et al. 2009) indicates that such a response in autumn is unlikely to be a result of differences in animal physiology during late lactation (autumn) compared with early lactation (spring). However, lower NDF at the same concentration of WSC could promote higher DM intake which alone would be expected to increase production. Furthermore, at the same concentration of WSC the HSG has more protein. This higher concentration of protein, in conjunction with the effect of greater DM intake and the associated increase in $\mathrm{N}$ intake, has a profound affect on $\mathrm{N}$ partitioning, particularly to urine.

Secondly, the slopes indicate that for every unit increase in WSC, protein decreased by 0.62 units in spring and 0.44 units in autumn, and NDF decreased by 0.30 units in spring and 0.17 in autumn. Crude protein and NDF together accounted for most of the changes in WSC. While the coefficients of determination are modest (the highest being 60-70\% for ash), there is nothing to suggest the slopes of any of the relationships differ for the selected high WSC ryegrass compared with the control perennial or with the Italian ryegrass. It has been argued that further increases in WSC are necessary to markedly improve the efficiency of $\mathrm{N}$ utilisation from the often high protein concentrations in New Zealand dairy pastures (Pacheco et al. 2007;
Edwards et al. 2007). Provided the same relationships for the effects on other constituents are maintained, further increases in WSC through management or selective breeding would have the associated effect of reducing the concentrations of protein and fibre. With reductions from current typical concentrations, less fibre should improve the nutritional value of ryegrass, and less protein should reduce urinary- $\mathrm{N}$ excretion.

The reasons for the apparent difference in slopes between spring and autumn are not obvious. There was substantial unexplained variation, possibly related to the day to day variation in concentration of WSC caused by variation in cloud cover and photosynthetic accumulation of soluble sugars. Further investigation, particularly removing day-to-day variation, may help to determine the basis for seasonal differences, as may more detailed analyses using multi-variate techniques.

\section{Conclusions}

Higher concentrations of WSC were offset mainly by reductions in protein and to a lesser extent in fibre, relationships which were similar for each cultivar of ryegrass. An increase in WSC and a decrease in protein and fibre are both likely to have a positive effect on nutritive value and animal performance in most situations. There will be exceptions to this, such as where low concentrations of protein or fibre might become limiting to nutrition or rumen function, or where high concentrations of WSC might exceed an optimum. Provided the relationships demonstrated here hold true with further efforts to increase WSC through management or breeding, nutritional and environmental benefits should continue to accrue from greater WSC and from the associated reductions in protein and fibre.

\section{ACKNOWLEDGEMENTS}

This project is funded by DairyNZ for the benefit of NZ dairy farmers. The contributions from Lex Foote for maintaining the experimental pastures and Mike Hickey for pasture sampling are gratefully acknowledged. We appreciate the enthusiastic support of the staff of Agricultural Services and the No 4 Dairy Unit, Massey University, in allowing access to farm facilities and services. Seed for the experimental pastures was contributed by NZ Agriseeds Ltd, and Germinal NZ Ltd.

\section{REFERENCES}

Cosgrove, G.P.; Burke, J.L.; Death, A.F.; Hickey, M.J.;

Pacheco, D.; Lane, G.A. 2007a. Ryegrasses with increased water soluble carbohydrate: evaluating the potential for grazing dairy cows in New Zealand. Proceedings of the New Zealand Grassland Association 69: 179-185.

Cosgrove, G.P.; Pacheco, D.; Burke, J.L.; Death, A.F.; 
Hickey, M.J.; Lane, G.A. 2007b. Effects of water soluble carbohydrate in forage on aspects of nitrogen partitioning in cows. pp. 350-358. In: Meeting the challenges for pasture-based dairying. Proceedings of the 3rd Dairy Science Symposium. Eds. Chapman, D.F.; Clark, D.A.; Macmillan, K.L.; Nation, D.P. National Dairy Alliance, Melbourne.

Edwards, G.R.; Parsons, A.J.; Rasmussen, S. 2007. High sugar grasses for dairy systems. pp. 307-334. In: Meeting the challenges for pasture-based dairying. Proceedings of the 3rd Dairy Science Symposium. Eds. Chapman, D.F.; Clark, D.A.; Macmillan, K.L.; Nation, D.P. National Dairy Alliance, Melbourne.

Hoekstra, N.J.; Struik, P.C.; Lantinga, E.A.; Schulte, R.P.O. 2007. Chemical composition of lamina and sheath of Lolium perenne as affected by herbage management. NJAS, Wageningen Journal of Life Sciences 55: 55-73.

Humphreys, M.O. 1989. Water-soluble carbohydrates in perennial ryegrass breeding. II. Cultivars and hybrid progeny performance in cut plots. Grass and Forage Science 44: 237-244.

Kingston-Smith, A.H.; Theodorou, M.K. 2000. Post-ingestion metabolism of fresh forage. New Phytologist 148: 37-55.

Lee, M.R.F.; Jones, E.L.; Moorby, J.M.; Humphreys, M.O; Theodorou, M.K.; MacRae, J.C.; Scollan, N.D. 2001. Production response from lambs grazed on Lolium perenne selected for an elevated water soluble carbohydrate concentration. Animal Research 50: 441-449.

Litherland, A.J.; Lambert, M.G. 2007. Factors affecting the quality of pastures and supplements. New Zealand Society of Animal Production, Occasional Publication No. 14: 81-96.

Miller, L.A.; Theodorou, M.K.; MacRae, J.C.; Evans, R.T.; Humphreys, M.O.; Scollan, N.D.; Moorby, J.M. 2000. Efficiency of nitrogen use by dairy cows offered perennial ryegrass with high water soluble carbohydrate concentrations. Proceedings of the 6 th British Grasslands Society Research Conference: 37-38.

Miller, L.A.; Baker, D.H.; Theodorou, M.K.; MacRae, J.C.; Humphreys, M.O.; Scollan, N.D.; Moorby, J.M. 2001a. Efficiency of nitrogen use in dairy cows grazing ryegrass with different water soluble carbohydrate concentrations. Proceedings XIX
International Grasslands Congress: 377-378.

Miller, L.A.; Moorby, J.M.; Davies, D.R.; Humphreys, M.O.; Scollan, N.D.; MacRae, J.C. Theodorou, M.K. 2001b. Increased concentration of water-soluble carbohydrate in perennial ryegrass (Lolium perenne L.): milk production from late-lactation dairy cows. Grass and Forage Science 56: 383-394.

Moorby, J.M.; Evans, R.T.; Scollan, N.D.; MacRae, J.C.; Theodorou, M.K. 2006. Increased concentration of water-soluble carbohydrate in perennial ryegrass (Lolium perenne L.). Evaluation in dairy cows in early lactation. Grass and Forage Science 61: 52-59.

Nocek, J.E.; Russell, J.B. 1988. Protein and energy as an integrated system. Relationship of ruminal protein and carbohydrate availability to microbial synthesis and milk protein. Journal of Dairy Science 70: 2070-2107.

Orr, R.J.; Rutter, S.M.; Penning, P.D.; Rook, A.J. 2001. Matching grass supply to grazing patterns for dairy cows. Grass and Forage Science 56: 352-361.

Pacheco, D.; Burke, J.L.; Cosgrove, G.P. 2007. An empirical model to estimate efficiency of nitrogen utilisation in cows grazing fresh forages. pp. 409-416. In: Meeting the challenges for pasture-based dairying. Proceedings of the 3rd Dairy Science Symposium. Eds. Chapman, D.F.; Clark, D.A.; Macmillan, K.L.; Nation, D.P. National Dairy Alliance, Melbourne.

Pacheco, D.; Lowe, K.; Burke, J.L.; Cosgrove, G.P. 2009. Urinary nitrogen excretion from cows at different stage of lactation grazing different ryegrass cultivars during spring or autumn. Proceedings of the New Zealand Society of Animal Production 69: 196-200.

Rasmussen, S.; Parsons A.J.; Xue, H.; Newman, J.A. 2009. High sugar grasses: harnessing the benefit of new cultivars through growth management. Proceedings of the New Zealand Grassland Association 71: 167-175.

Tas, B.M.; Taweel, H.Z.; Smit, H.J.; Elgersma, A.; Dijkstra, J.; Tamminga, S. 2005. Effects of perennial ryegrass cultivars on intake, digestibility, and milk yield in dairy cows. Journal of Dairy Science 88: 3240-3248. 